\title{
Evidence related to sodium restriction in patients with heart failure
}

\author{
Evidências relacionadas à restrição de sódio em pacientes com insuficiência cardíaca \\ Pruebas relacionadas con la restricción de sodio en pacientes con insuficiencia cardíaca
}

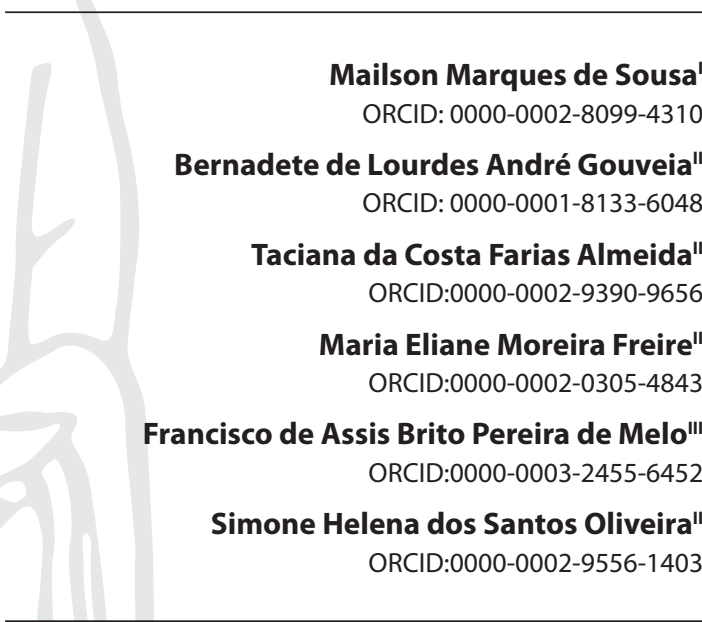

'Hospital Municipal Santa Isabel. João Pessoa, Paraíba, Brazil. "Universidade Federal da Paraíba. João Pessoa, Paraíba, Brazil "'Centro Universitário de João Pessoa. João Pessoa, Paraíba, Brazil.

How to cite this article: Sousa MM, Gouveia BLA, Almeida TCF, Freire MEM, Melo FABP, Oliveira SHS. Evidence related to sodium restriction in patients with heart failure.

Rev Bras Enferm. 2020;73(4):e20180874. doi: http://dx.doi.org/10.1590/0034-7167-2018-0874

Corresponding author: Mailson Marques de Sousa E-mail: mailson_ms@hotmail.com

EDITOR IN CHIEF: Dulce Aparecida Barbosa ASSOCIATE EDITOR: Mitzy Danski

\section{ABSTRACT}

Objectives: to analyze the scientific production about sodium restriction in patients with heart failure. Methods: integrative literature review from articles published from 2007 to 2017, located in the CINAHL and Scopus databases. Results: thirteen studies were analyzed. Sodium intake restriction was associated with lower unfavorable clinical outcomes in patients with marked symptomatology. The 24-hour urine sodium dosage was the main tool to assess adherence to the low sodium diet. Conclusions: based on the studies included in this review, in symptomatic patients, dietary sodium restriction should be encouraged in clinical practice as a protective measure for health. However, in asymptomatic patients, it should be well studied.

Descriptors: Evidence-Based Nursing; Cardiac Failure; Diet, Sodium-Restricted; Diet Therapy; Patient Compliance.

\section{RESUMO}

Objetivos: analisar a produção científica acerca da restrição de sódio em pacientes com insuficiência cardíaca. Métodos: revisão integrativa da literatura, a partir de artigos publicados no período de 2007 a 2017, localizados nas bases de dados CINAHL e Scopus. Resultados: foram analisados 13 estudos. A restrição no consumo de sódio se mostrou associada a menores desfechos clínicos desfavoráveis em pacientes com sintomatologia acentuada. A dosagem de sódio na urina coletada em 24 horas foi a ferramenta principal para avaliar adesão à dieta com baixo teor de sódio. Conclusões: com base nos estudos incluídos nesta revisão, em pacientes sintomáticos, a restrição de sódio na dieta deve ser encorajada na prática clínica como medida protetora à saúde. No entanto, em pacientes assintomáticos, deve ser bem estudada.

Descritores: Enfermagem Baseada em Evidências; Insuficiência Cardíaca; Dieta Hipossódica; Dietoterapia; Cooperação do Paciente.

\section{RESUMEN}

Objetivo: analizar la producción científica sobre la restricción de sodio en pacientes con insuficiencia cardíaca. Métodos: revisión integral de la literatura de artículos publicados de 2007 a 2017, ubicados en las bases de datos CINAHL y Scopus. Resultados: se analizaron trece estudios. La restricción en la ingesta de sodio se asoció con resultados clínicos desfavorables más bajos en pacientes con marcada sintomatología. La dosis de sodio en orina de 24 horas fue la herramienta principal para evaluar el cumplimiento de la dieta baja en sodio. Conclusión: según los estudios incluidos en esta revisión, en pacientes sintomáticos, se debe fomentar la restricción de sodio en la dieta en la práctica clínica como medida de protección para la salud. Sin embargo, en pacientes asintomáticos, debe estudiarse bien.

Descriptores: Enfermería Basada en la Evidencia; Insuficiencia Cardíaca; Dieta Hiposódica; Dietoterapia; Cooperación del Paciente. 


\section{INTRODUCTION}

Within the scope of cardiovascular system disorders is heart failure (HF), a chronic disease of complex and systemic character, considered as the final pathway of most heart diseases. HF is currently a challenge for health teams in promoting strategies that favor their clinical stability, given the complex therapeutic regimen proposed to minimize progressions in cardiac remodeling and decompensation crises $^{(1)}$.

According to data from the Ministry of Health's Brazilian Health Information System (DATASUS), from 2016 to 2017, 422,921 HF hospital admissions were authorized. In this biennium, a mortality rate of $10.93 \%$ was registered, and high financial costs were evidenced for the public health system ${ }^{(2)}$. It is estimated that around 26 million people worldwide are diagnosed with $\mathrm{HF}^{(3)}$.

Evidence shows that about $50 \%$ of Patients with $\mathrm{HF}$ are readmitted 90 days after hospital discharge with acute clinical decompensation $^{(4-5)}$. Among the most frequent causes of unwanted readmissions, the low adherence to the therapy instituted for the management of the disease stands out. Pharmacological and non-pharmacological therapeutic measures are essential for maintaining functional capacity, survival and quality of life in Patients with $\mathrm{HF}^{(6)}$.

These include dietary sodium restriction as a non-pharmacological recommendation, which is necessary and widely prescribed as part of lifestyle changes for Patients with HF. Although sodium intake restriction is indicated to minimize exacerbations of disease symptoms and deleterious effects on the myocardium, this recommendation diverges between guidelines on optimal sodium intake for health maintenance. This is due to the variety of methods applied in research, making it difficult to generalize the results ${ }^{(7-8)}$.

Overall, a daily sodium intake of around 2-3 g/day is suggested. However, it should be emphasized that sodium restriction should be adapted to the patient's clinical picture, as well as to the pharmacological therapy employed in the treatment, especially diuretics use ${ }^{(8)}$.

Despite its importance, research indicates low adherence of patients with HF to sodium restriction in diet therapy, favoring a higher risk for acute events, hospitalizations and unfavorable clinical outcomes $^{(9-11)}$. A multicenter Brazilian study aimed at outlining the clinical characteristics, treatment and prognosis of patients with acute $\mathrm{HF}$ conducted in the five regions of the country found that $8.9 \%$ of the causes of clinical decompensation for HF were due to inadequate sodium and fluid intake. Authors showed that only $34.9 \%$ of patients received guidance at hospital discharge on the importance of following a low sodium diet ${ }^{(5)}$.

When reviewing the literature, there is a lack of studies on the phenomenon in Brazilian journals. It is considered necessary to deepen the theme with the perspective of improving the quality of care offered to Patients with HF, as well as subsidizing the design of care technologies for self-care management and change of risk behaviors. In addition, the evidence produced synthesis in this study provides relevant information for evidence-based decision-making for clinical nurse practice.

\section{OBJECTIVES}

To analyze the scientific production about sodium restriction in Patients with HF.

\section{METHODS}

Integrative review study (IR), which followed the following steps: research question identification; study inclusion and exclusion criteria definition; study categorization and assessment; results extraction and interpretation; and knowledge synthesis ${ }^{(12)}$. The research question underlying this review was: what is the state of the art related to sodium restriction in the diet of patients with heart failure?

To select the articles included in the review, the Scopus and Cumulative Index to Nursing and Allied Health Literature (CINAHL) databases were consulted. These two bases were chosen because they include the main health and nursing journals.

To elaborate the search strategies in the databases, we used the acronym PICO ${ }^{(13)}$, where $\mathrm{P}$ stands for Patients with HF; I for dietary sodium restriction; $\mathrm{C}$ for there was no comparison; $\mathrm{O}$ for diet therapy. We used the descriptors related to the research question in English, because all journals indexed in the selected databases have in their articles descriptors in that language. The descriptors heart failure, sodium, diet therapy were crossed using the Boolean operator "AND" between them.

Article tracing was performed in February 2018. The search took place over an 11-year timeframe (surveys published from 2007 to 2017) and covered full-text articles. As inclusion criteria, primary studies were adopted, available in full online, in English, Portuguese and Spanish. Duplicate articles in the databases, theses and dissertations, as well as opinion articles and editorials were excluded.

The research was conducted by two independent reviewers who read the title and abstract. When the title and summary of the studies were not clear, the full article was read. After article selection, information from the selected studies was extracted from a synoptic table prepared by the authors containing the following information: title of the publication, authors, year, journal, language, objectives, methodological design, sample, methods to measure the restriction of sodium, results, and conclusion.

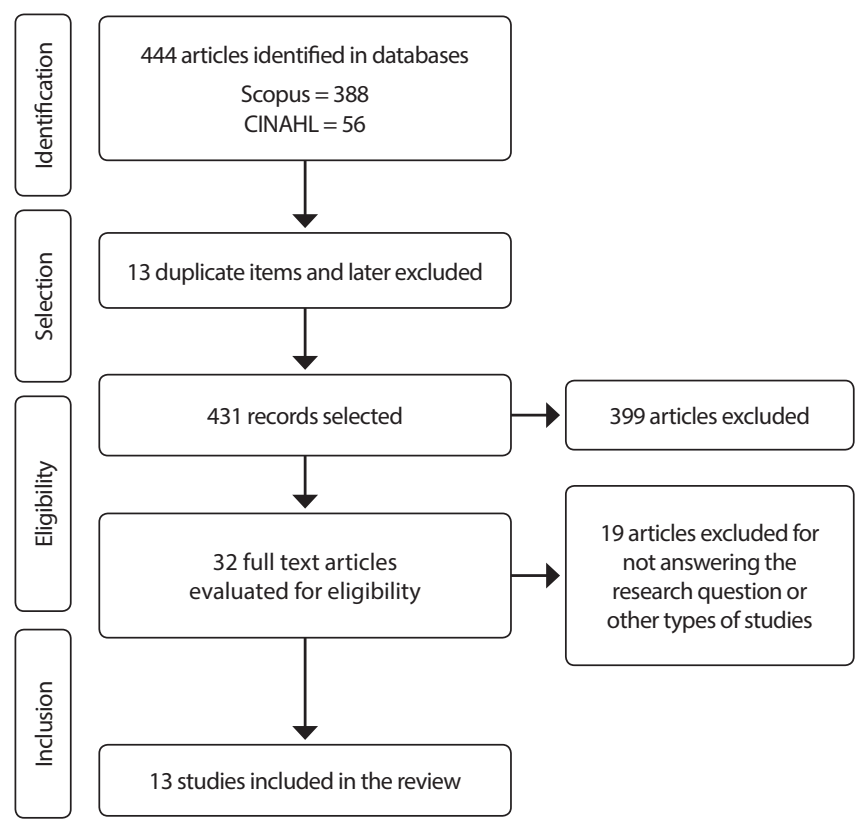

Figure 1 - Flowchart of the selection process of articles included in integrative review, meeting the PRISMA criteria(15), João Pessoa, Paraíba, Brazil, 2018 
Following, the selected studies were classified according to the level of evidence (LoE) proposed by Melnyk, Fineout-Overholt: I - Systematic reviews or meta-analysis of relevant clinical trials; II Evidence from at least one well-designed randomized controlled trial; III - Well-outlined clinical trials without randomization; IV - Cohort and case-control studies; $V$ - Systematic review of descriptive and qualitative studies; $\mathrm{VI}$-Evidence derived from a single descriptive or qualitative study; VII - Opinion of authorities or expert committees including interpretations of non-research based information ${ }^{(14)}$. Figure 1 shows the flowchart of the selection process of the articles of this review, meeting the PRISMA criteria ${ }^{(15)}$.

\section{RESULTS}

Among the 13 eligible articles, all were populated in the English language. Chart 1 summarizes the articles included in this review.
Regarding the countries where the investigations were conducted, the United States stands out, with the largest number

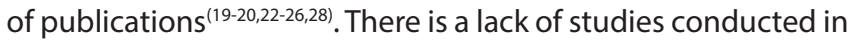
Latin America. The period in which the articles were published is from 2008 to 2016. Regarding the level of evidence (LoE), three studies $^{(16-17,20)}$ were outlined through a randomized clinical trial (level of evidence II), seven articles ${ }^{(18-19,21-22,25,27-28)}$ covered cohort studies (level of evidence IV), and three publications ${ }^{(23-24,26)} \mathrm{de}-$ rived from descriptive or qualitative studies (level of evidence $\mathrm{VI}$ ).

In the analyzed studies, the sample ranged from 16 to 902 participants. Most were male, were married, had ischemic cardiomyopathy and were in functional class II according to the New York Heart Association criteria (NYHA). To measure the sodium intake of the investigated sample, 7 studies used the 24-hour urinary sodium exam ${ }^{(17-18,24-28)}$. The Dietary Sodium Restriction Questionnaire (DSRQ) tool was used in five investigations ${ }^{(16,20,24-26)}$.

Chart 1 - Characteristics of sodium restriction studies in Patients with Heart Failure, João Pessoa, Paraíba, Brazil, 2018

\begin{tabular}{|c|c|c|c|c|c|}
\hline Reference & $\begin{array}{l}\text { Year/ } \\
\text { Country }\end{array}$ & Outlining & Objectives & Outcomes & LoE \\
\hline $\begin{array}{l}\text { Colin- } \\
\text { Ramirez E } \\
\text { et al. }{ }^{(16)}\end{array}$ & $\begin{array}{c}2015 \\
\text { Canada }\end{array}$ & $\begin{array}{l}\text { Randomized } \\
\text { clinical trial } \\
\quad \mathrm{n}=38\end{array}$ & $\begin{array}{l}\text { To determine the feasibility of a randomized } \\
\text { controlled trial comparing a low sodium } \\
\text { diet with a moderate sodium diet. }\end{array}$ & $\begin{array}{l}\text { After six months, sodium intake decreased in both } \\
\text { groups. In addition, there was an improvement in } \\
\text { the perception of quality of life. }\end{array}$ & II \\
\hline $\begin{array}{l}\text { Paterna S } \\
\text { et al. }{ }^{(17)}\end{array}$ & $\begin{array}{l}2008 \\
\text { Italy }\end{array}$ & $\begin{array}{c}\text { Randomized } \\
\text { clinical trial } \\
n=232\end{array}$ & $\begin{array}{l}\text { To assess the effects of a normal sodium } \\
\text { diet ( } 120 \mathrm{mmol} \text { sodium) compared to a } \\
\text { low sodium diet ( } 80 \mathrm{mmol} \text { sodium) on HF } \\
\text { readmissions. }\end{array}$ & $\begin{array}{l}\text { The group with normal sodium diet had lower } \\
\text { incidence of reincarnation. The sodium-restricted } \\
\text { diet produced harmful renal and neurohormonal } \\
\text { effects in patients with clinically compensated HF. }\end{array}$ & II \\
\hline $\begin{array}{l}\text { Son YJ et } \\
\text { al. }{ }^{(18)}\end{array}$ & $\begin{array}{l}2011 \\
\text { Korea }\end{array}$ & $\begin{array}{c}\text { Quantitative } \\
\text { cohort study } \\
n=232\end{array}$ & $\begin{array}{l}\text { To determine whether adherence to a } \\
\text { sodium-restricted diet affects symptom } \\
\text { burden and cardiac event-free survival in } \\
\text { Patients with HF. }\end{array}$ & $\begin{array}{l}\text { Patients with } \geq 3 \text { g sodium intake per day exhibited } \\
\text { lower cardiac event-free survival. Limited sodium } \\
\text { intake }<3 \mathrm{~g} / \text { day showed improvement in HF } \\
\text { symptomatology. }\end{array}$ & IV \\
\hline $\begin{array}{l}\text { Basuray A } \\
\text { et al. }{ }^{(19)}\end{array}$ & $\begin{array}{l}2015 \\
\text { USA }\end{array}$ & $\begin{array}{c}\text { Quantitative } \\
\text { cohort study } \\
n=305\end{array}$ & $\begin{array}{l}\text { To determine sodium restriction rates and } \\
\text { predictors and to assess the reliability } \\
\text { of } 24 \text {-hour urine collection as a tool to } \\
\text { estimate dietary sodium intake in Patients } \\
\text { with HF. }\end{array}$ & $\begin{array}{l}\text { The mean } 24 \text {-hour urinary sodium excretion was } \\
3.15 \pm 1.58 \mathrm{~g} / \text { day. Logistic regression analysis } \\
\text { showed male gender and high body mass index } \\
\text { as predictors associated with non-adherence to } \\
\text { sodium restriction. }\end{array}$ & IV \\
\hline $\begin{array}{l}\text { Welsh D et } \\
\text { al. }{ }^{(20)}\end{array}$ & $\begin{array}{l}2013 \\
\text { USA }\end{array}$ & $\begin{array}{c}\text { Randomized } \\
\text { clinical trial } \\
n=52\end{array}$ & $\begin{array}{l}\text { To examine the effectiveness of an } \\
\text { educational intervention (counseling, } \\
\text { home visits, and telephone monitoring) } \\
\text { in reducing the dietary sodium intake of } \\
\text { Patients with HF. }\end{array}$ & $\begin{array}{l}\text { Dietary sodium intake did not differ between the } \\
\text { usual care and intervention groups at } 6 \text { weeks; } \\
\text { however, dietary sodium intake was lower in the } \\
\text { intervention group at } 6 \text { months. }\end{array}$ & II \\
\hline $\begin{array}{c}\text { Colin- } \\
\text { Ramirez E } \\
\text { et al. } .^{(21)}\end{array}$ & $\begin{array}{l}2015 \\
\text { Canada }\end{array}$ & $\begin{array}{l}\text { Quantitative } \\
\text { cohort study n } \\
\quad=237\end{array}$ & $\begin{array}{l}\text { To assess the association between self- } \\
\text { reported adherence to a low sodium } \\
\text { diet and dietary habits related to sodium } \\
\text { intake in Patients with HF. }\end{array}$ & $\begin{array}{l}\text { Self-reported adherence to a low sodium diet was } \\
\text { not reliable among Patients with HF. It was found } \\
\text { that the self-reported measure was associated with } \\
\text { not adding salt in the preparation of meals or at } \\
\text { the table. However, there was no reduction in the } \\
\text { frequency of ingestion of high sodium foods. }\end{array}$ & IV \\
\hline $\begin{array}{l}\text { Doukky R } \\
\text { et al. }{ }^{(22)}\end{array}$ & $\begin{array}{l}2016 \\
\text { USA }\end{array}$ & $\begin{array}{c}\text { Quantitative } \\
\text { cohort study } \\
n=902\end{array}$ & $\begin{array}{l}\text { To assess the impact of sodium restriction } \\
\text { on the outcomes of patients with HF. }\end{array}$ & $\begin{array}{l}\text { Results did not show that dietary sodium restriction } \\
\text { is associated with lower death or hospitalization } \\
\text { rates in Patients with HF. In patients who did not } \\
\text { use angiotensin-converting enzyme inhibitors or } \\
\text { angiotensin receptor blockers, sodium restriction } \\
\text { showed detrimental neurohormonal changes. }\end{array}$ & IV \\
\hline $\begin{array}{l}\text { Heo S et } \\
\text { al. }^{(23)}\end{array}$ & $\begin{array}{l}2009 \\
\text { USA }\end{array}$ & $\begin{array}{l}\text { Qualitative } \\
\text { study } \\
n=20\end{array}$ & $\begin{array}{l}\text { To explore Patients with HF' perceptions } \\
\text { of foods that impact their disease, } \\
\text { their understanding of the nutritional } \\
\text { recommendations received, and the } \\
\text { factors that affect recommendations for } \\
\text { following a low sodium diet. }\end{array}$ & $\begin{array}{l}\text { Most patients believed that eating high sodium } \\
\text { foods could affect their health. Nevertheless, less } \\
\text { than half understood that excessive sodium intake } \\
\text { could accentuate the symptoms of HF. Knowledge, } \\
\text { social influence, social conditions and diet as a } \\
\text { source of pleasure affect the follow-up of a low } \\
\text { sodium diet. }\end{array}$ & $\mathrm{VI}$ \\
\hline
\end{tabular}




\begin{tabular}{|c|c|c|c|c|c|}
\hline Reference & $\begin{array}{c}\text { Year/ } \\
\text { Country }\end{array}$ & Outlining & Objectives & Outcomes & LoE \\
\hline $\begin{array}{l}\text { Wu JR et } \\
\text { al. }^{(24)}\end{array}$ & $\begin{array}{l}2016 \\
\text { USA }\end{array}$ & $\begin{array}{l}\text { Cross-sectional } \\
\text { quantitative } \\
\text { study } \\
n=244\end{array}$ & $\begin{array}{l}\text { To determine which factors were } \\
\text { associated with sodium intake in Patients } \\
\text { with HF using Theory Planned Behavior. }\end{array}$ & $\begin{array}{l}\text { New York Heart Association subjective standards, } \\
\text { gender, and functional class were associated with } \\
\text { sodium intake. }\end{array}$ & VI \\
\hline $\begin{array}{l}\text { Chung ML } \\
\text { et al. }{ }^{(25)}\end{array}$ & $\begin{array}{l}2016 \\
\text { USA }\end{array}$ & $\begin{array}{l}\text { Quantitative } \\
\text { cohort study } \\
n=74\end{array}$ & $\begin{array}{l}\text { To compare sodium intake measured } \\
\text { by } 24 \text {-hour urinary sodium excretion } \\
\text { between patients, categorized by self- } \\
\text { report, as adherent over } 6 \text { months and } \\
\text { non-adherent. }\end{array}$ & $\begin{array}{l}\text { The long-term adherent group had lower sodium } \\
\text { intake ( } \leq 3 \mathrm{~g} \text { ) and realized greater benefits from } \\
\text { following a low sodium diet (reduced body edema, } \\
\text { improved breathing pattern and increased feeling of } \\
\text { well-being) compared with the non-adherent group. }\end{array}$ & IV \\
\hline $\begin{array}{l}\text { Lennie TA } \\
\text { et al. }^{(26)}\end{array}$ & $\begin{array}{l}2008 \\
\text { USA and } \\
\text { Australia }\end{array}$ & $\begin{array}{l}\text { Cross-sectional } \\
\text { quantitative } \\
\text { study } \\
n=246\end{array}$ & $\begin{array}{l}\text { To describe HF patient's perceptions } \\
\text { regarding the instructions received to } \\
\text { follow a low sodium diet and the benefits, } \\
\text { barriers, ease as well as frequency of } \\
\text { following the diet. }\end{array}$ & $\begin{array}{l}\text { Of the patients, } 80 \% \text { reported receiving } \\
\text { recommendations to follow a low sodium diet. } \\
\text { However, } 24 \text {-hour urinary sodium excretion } \\
\text { showed that only } 25 \% \text { of patients were adherent. } \\
\text { Limited information is pointed as barriers to the } \\
\text { follow-up of a low sodium diet. }\end{array}$ & VI \\
\hline $\begin{array}{c}\text { Song EK et } \\
\text { al. }^{(27)}\end{array}$ & $\begin{array}{c}2016 \\
\text { Korea }\end{array}$ & $\begin{array}{l}\text { Quantitative } \\
\text { cohort study } \\
\mathrm{n}=119\end{array}$ & $\begin{array}{l}\text { To determine whether self-reported } \\
\text { adherence is consistent with a low } \\
\text { sodium diet as measured by food } \\
\text { questionnaires and urinary sodium } \\
\text { excretion; and whether self-reported } \\
\text { adherence to a low sodium diet is a } \\
\text { predictor free of cardiac events. }\end{array}$ & $\begin{array}{l}\text { Self-reported adherence was consistent with the } \\
\text { measurement of food questionnaires and } 24 \text {-hour } \\
\text { urinary sodium excretion. Patients who reported } \\
\text { never or rarely following a low sodium diet were } 4.7 \\
\text { times more likely to have cardiac events than those } \\
\text { who always followed a low sodium diet. }\end{array}$ & IV \\
\hline $\begin{array}{l}\text { Lennie TA } \\
\text { et al. }^{(28)}\end{array}$ & $\begin{array}{l}2011 \\
\text { USA }\end{array}$ & $\begin{array}{l}\text { Quantitative } \\
\text { cohort study } \\
n=302\end{array}$ & $\begin{array}{l}\text { To compare differences in cardiac event- } \\
\text { free survival between patients with } \\
\text { sodium intake above and below } 3 \mathrm{~g} \text {. }\end{array}$ & $\begin{array}{l}\text { Results showed that } 3 \mathrm{~g} / \text { day of sodium in dietary } \\
\text { restriction may be more appropriate for Patients } \\
\text { with HF with marked symptomatology. }\end{array}$ & IV \\
\hline
\end{tabular}

\section{DISCUSSION}

In response to the research question that guided the search for articles in the databases, the evidence found indicates that sodium restriction in patients with HF is not fully incorporated into health protective measures' behavior in this population.

Although widely indicated, there is no consensus in the literature about optimal sodium intake for Patients with HF. However, excessive sodium consumption by these patients causes a series of neurohormonal changes due to reduced cardiac function, elevated systemic venous pressure and decreased renal perfusion; therefore, exacerbated activation of the renin-angiotensin-aldosterone system occurs. These changes trigger a vicious cycle of sodium and water retention, which favors the onset of pulmonary and systemic congestion $^{(7-9)}$.

In our findings, a cohort study of 302 patients found that NYHA functional class III/IV patients with sodium intakes greater than $3 \mathrm{~g}$ /day were 2.5 times more likely to have readmissions or deaths ${ }^{(28)}$. Another study conducted with 232 patients followed for 12 months found that patients not adhering to a $3 \mathrm{~g} /$ day sodium diet had worsening symptoms and 2 times more chances of acute clinical decompensation ${ }^{(18)}$.

Randomized clinical trial assessing the effects of a normal sodium diet ( $120 \mathrm{mmol}$ sodium $/ 2.8 \mathrm{~g}$ ) compared to a low sodium diet ( $80 \mathrm{mmol}$ sodium $/ 1.8 \mathrm{~g}$ ) associated with a high dose diuretic (furosemide, 250-500 mg) and water restriction (1,000 ml/day) in readmissions of Patients with $\mathrm{HF}$, concluded that normal sodium intake combined with appropriate diuretic therapy can maintain intravascular stability and decrease rehospitalization rate ${ }^{(17)}$. Another study comparing a low sodium diet $(1.5 \mathrm{~g} / \mathrm{d}$ ) with a moderate sodium diet $(2.3 \mathrm{~g} / \mathrm{d}$ ) for 6 months showed that patients with lower sodium intake had decreased vascular volume overload levels and a better perception of quality of life $\mathrm{e}^{(16)}$.

However, a cohort approach conducted with 902 participants, which investigated the impact of sodium restriction on the outcomes of patients with HF, found no association between a lower mortality rate and a decrease in sodium-related hospitalizations. Authors consider that sodium restriction in NYHA functional class I and II patients may be unsatisfactory due to neurohormonal activation and prescribed pharmacological therapy (diuretics). This may not have satisfactory benefits in maintaining the clinical stability of the disease ${ }^{(22)}$.

In the literature analyzed, it is clear that, in patients with severe symptoms, especially in NYHA classes III and IV, sodium consumption restriction has been associated with lower unfavorable clinical outcomes. However, in NYHA class I and II patients categorized with no symptoms or effort-triggered symptoms, there is a paucity of studies on optimal sodium consumption to minimize advances in cardiac remodeling and increased volume overload.

The findings are divergent in view of the diversity of methodological designs applied in the investigations, the clinical conditions of the sample, as well as the study follow-up period. Another aspect to be considered is the use of the pharmacological therapy employed, especially the diuretic dose and the hydrosaline restriction adopted in the research protocol, which makes it impossible to generalize the results.

It is considered pertinent to analyze that water restriction associated with sodium restriction may have influenced the findings. Limiting fluid intake to 1.5-2 L/day is advised only in severe Patients with $\mathrm{HF}$ with signs of congestion or hyponatremia ${ }^{(29)}$. Moreover, the benefits of this recommendation are controversial due to hemodynamic changes and progressive cardiac remodeling in chronic HF. 
The cultural context where the research was developed stands out. The phenomenon in question has been explored in industrialized countries with distinct cultural habits and lifestyles. Added to this is the greater purchasing power for consumer goods, which favors the ingestion of canned and ultra-processed foods that have a high concentration of sodium content.

It is imperative that comparative multicenter prospective investigations be conducted in order to produce consistent evidence of optimal sodium intake in Patients with HF. It should be noted that the benefits found are associated with sodium intake restriction, disease functional class or the effect of diuretic therapy employed.

Although findings on optimal sodium intake for Patients with $\mathrm{HF}$ are controversial due to the divergence of methods and protocols employed in the investigations, as well as the lack of consensus on therapeutic guidelines, it is irrefutable to educate and guide them to restrict your intake. Excess sodium is a risk factor for diseases such as systemic arterial hypertension, ventricular hypertrophy and nephropathies that may accentuate the clinical condition of $\mathrm{HF}^{(30-31)}$.

Thus, it is suggested that these patients be advised not to add salt to prepared foods, to abolish table salt shakers and to replace salt with fresh herbs and spices when preparing meals. It is also recommended to exclude the food menu, chilled ready meals and embedded foods, which concentrate high sodium content in the preservation process. These strategies are inexpensive and should be incorporated into behavior change necessary to maintain the functional capacity and clinical stability of Patients with HF.

Since HF is a chronic and progressive disease, without the therapeutic possibility of cure, it is important to identify which factors can facilitate or hinder the follow-up of a low sodium diet. From this perspective, in our findings, there is a study with a sample of 246 participants that aimed to describe the perceptions, facilities and barriers to following a low sodium diet. Authors identified that $80.1 \%$ of participants received advice on following a sodiumrestricted diet, such as controlling salt intake, not adding salt to cooked foods, and leaving table salt available. However, 54\% said it was difficult or very difficult to follow these guidelines ${ }^{(26)}$.

In addition, 70\% of dietary sodium was from processed foods. Not knowing how to choose low sodium meals in restaurants was considered a barrier. Additionally, the non-adherence of family members to share a low sodium diet, as well as social life, were difficulties identified ${ }^{(26)}$. These facts reinforce the need to incorporate the social support network (family, friends) in the educational process of Patients with HF. Added to this is the need to advise them on the health effect of excessive sodium intake, as well as the strategies that can be used to replace processed foods on the food menu.

Another study with a qualitative approach conducted in the United States found similar results. $85 \%$ of respondents received specific guidelines regarding dietary sodium restriction, but only $60 \%$ reported following it. Among the factors related to non-adherence to a low sodium diet was lack of knowledge; social and family pressure; socioeconomic conditions; difficulty finding low sodium meals in restaurants; and food as a source of pleasure and satisfaction ${ }^{(23)}$.

It is understood that the impact and physical and psychosocial limitations inherent to HF may influence adherence to prescribed therapy. Thus, it is considered irrefutable to outline systematic educational interventions to enhance the understanding and understanding of the benefits and harms of dietary sodium restriction, considering beliefs, habits, socioeconomic conditions and family contexts. It is noteworthy that there are still incipient studies conducted in the national scenario aiming to analyze the determinants of reduced dietary sodium intake in Patients with HF.

Regarding the methods applied for data collection in the analyzed studies, one factor to highlight is the use of different procedures and protocols for this purpose. It was observed the use of 24-hour urine sodium dosage as the main tool to assess adherence to the low sodium diet in the investigations ${ }^{(19,22,24-25,27)}$.

The 24-hour urine sodium test is a biomarker, considered the gold standard for measuring daily sodium intake, since $90 \%$ of the sodium excreted through the urine is given by salt consumption ${ }^{(30-31)}$.

A study conducted with 119 participants, whose objective was to determine whether self-reported adherence agrees with adherence to a low sodium diet, measured by daily food intake and 24-hour urinary sodium dosage, showed agreement between the results. Authors found by regression analysis that within one year, participants who reported never or rarely following a low sodium diet (daily intake $>4 \mathrm{~g}$ ) were 4.7 times more likely to exhibit compared with those on a low sodium diet $(<3 \mathrm{~g} / \text { day; } \mathrm{p}=0.017)^{(27)}$.

Another study comparing adherence to a low sodium diet (adherent versus non-adherent), measured by 24-hour urinary sodium excretion, found that the adherent group had $27 \%$ lower urinary sodium excretion than the non-adherent group $(\leq 3 \mathrm{~g}$ vs. $\geq 4 \mathrm{~g}, \mathrm{p}=0.01$, respectively) after 6 months of follow-up ${ }^{(25)}$.

Another investigation analyzed the reliability of the urinary sodium test in a 24-hour diuresis collection as a tool to estimate dietary sodium intake in $305 \mathrm{HF}$ outpatients with reduced ejection fraction (<40\%). Authors found by logistic regression analysis that men and high body mass index were associated with poor adherence to lower sodium diet $(<3 \mathrm{~g} / \text { day })^{(19)}$.

It is understood that the urinary sodium excretion exam is a reliable and enlightening tool in clinical practice. Its use in the assessment of Patients with HF' behavior in following a low sodium diet is indispensable, considering that only the use of questionnaires and/ or food diaries can underestimate their consumption. Self-report may be influenced by economic, cultural and cognitive conditions.

Among the surveys, it was found that the Dietary Sodium Restriction Questionnaire (DSRQ) was the most used among the various tools available in the literature to assess sodium intake. Based on Theory Planned Behavior (TPB), DSRQ is aimed at measuring the factors that facilitate or hinder adherence to a sodium-restricted diet and has reliability and reproducibility measures proven in the literature ${ }^{(32)}$.

Composed of three subscales, the mentioned tool involves statements that assess the following constructs: 1) attitude - is related to the subject's favorability regarding behavior performance or non-performance; 2 ) subjective norm - represents the perceived social pressure, that is, it is based on the individual's perception about the opinions of their social referents about behavior performance or non-performance; 3 ) behavior control - composed of items that assess the individual's perceptions regarding the perceived ease or difficulty in behavior performance ${ }^{(32-33)}$.

A study that determined factors associated with TPB sodium intake concluded that the New York Heart Association's subjective 
standard, gender, and functional class were associated with lower sodium intake $(p<0.001)$. Authors point out that having approval from spouse, family members and/or health care providers emerges as a significant positive influence on adherence to a hyposodic diet ${ }^{(24)}$.

The literature has pointed to the role of the social support network as adjuvants in adhering to the therapy instituted in patients with HF. As social network members, they are spouses, children, neighbors, health professionals, among others. Family participation in the educational process of this population is essential for patients'motivation and adherence to the prescribed lifestyle change recommendations to maintain the clinical stability of the disease ${ }^{(34)}$.

It is important to emphasize that the formation of bonds between health professionals and service users is fundamental to close gaps and promote confidence in the prescribed therapeutic approach. In most situations, this bond is considered a positive referent for health care. It is important that care for patients with HF be performed in a multidisciplinary, holistic manner and integrated with their social support network, in order to strengthen the pharmacological and non-pharmacological disease management, as well as quality of life.

Of all studies, only one aimed to examine the effectiveness of an educational intervention in reducing dietary sodium intake in the subscales that make up the Dietary Sodium Restriction Questionnaire (attitude, subjective norm, and perceived behavioral control). Intervention group participants received guidance for six weeks through home visits or telephone instructions on the consumption of a high-sodium diet and its relationship to exacerbation of signs and symptoms of pulmonary congestion, choosing lower sodium foods and tips for choosing healthy foods when dining out. Authors found higher attitude subscale score in the intervention group $(n=27)$ after six weeks when compared to the control group $(n=25)$ that received guidance $(p<0.01)^{(20)}$.

These results provide support for the development of educational interventions based on behavioral theories. These interventions opened new perspectives for nursing in the design of care technologies that may favor the change of beliefs and health risk behaviors. Measurement tools anchored in TPB seem to be adequate to study the motivational factors that determine the behavior of reducing sodium intake in the diet.

DSRQ was adapted and validated for Brazilian Portuguese ${ }^{(35)}$. Nevertheless, it is understood that the use of tools produced in different contexts may not be adequate to assess certain phenomena in culturally distinct regions. Moreover, according to TPB, to measure the determinant factors of behavior performance, it is essential to elucidate salient beliefs of the target audience. The inherent aspects of the context in which it is intended to investigate and intervene must be considered ${ }^{(33)}$.
From the belief survey, a questionnaire is designed with direct and indirect measures to measure behavioral intention, considered the immediate antecedent of behavior. Measurement tools to assess psychosocial factors determining dietary sodium intake restriction should be constructed from the local context, since important elements may not be covered by previously validated tools.

\section{Study limitations}

Authors were restricted to publications in only three languages (Portuguese, English and Spanish), which may have limited access to other relevant findings. It was observed that in this review, investigations with cohort design prevailed, a fact that makes it impossible to establish robust evidence on the effect of dietary sodium restriction in patients with HF. In addition, there is a scarcity of Latin American productions on the theme.

\section{Contributions to nursing, health or public policy}

This IR synthesized the knowledge about sodium restriction in patients with HF. It is expected that, based on the findings highlighted in this study, future investigations may be conducted with robust methods and protocols to produce consistent evidence of sodium restriction, a determining factor for decompensation or acute clinical status in Patients with HF. It is noteworthy that the reduction of sodium intake is a worldwide goal to be achieved and was assumed by Brazil in the Plan for the Prevention and Control of Chronic Noncommunicable Diseases proposed by the World Health Organization.

Incorporating evidence into nurses' clinical practice can help them implement theories and motivational strategies based on theories to change beliefs, attitudes, habits and risk behaviors according to cultural and socioeconomic contexts; reduce complications from HF due to non-follow-up of a low sodium diet; and provide grants for nurses in decision-making.

\section{CONCLUSIONS}

The results of this review showed that there is no consensus in the literature on dietary sodium restriction in patients with HF. Although studies have different methodologies and protocols, sodium restriction should be encouraged in clinical practice as a protective measure for health, in order to reduce unfavorable clinical outcomes in patients with advanced symptoms. However, the results suggest that the effect of low sodium diets needs to be well studied in asymptomatic patients. Therefore, it is imperative to carry out further investigations on a larger scale and to assess long-term consequences of this recommendation.

\section{REFERENCES}

1. Comitê Coordenador da Diretriz de Insuficiência Cardíaca. Diretriz Brasileira de Insuficiência Cardíaca Crônica e Aguda. Arq Bras Cardiol [Internet]. 2018 [cited 2018 Oct 01];111 (3):436-539. Available from: http://publicacoes.cardiol.br/portal/abc/portugues/2018/v11103/pdf/11103021.pdf

2. Ministério da Saúde (BR). Datasus [Internet]. Brasília, DF. Sistema de Informações Hospitalares do SUS (SIH/SUS). 2018 [citado 2018 Mar 17]. Available from: http://tabnet.datasus.gov.br/cgi/tabcgi.exe?sih/cnv/niuf.def

3. Mesquita ET, Jorge AJL, Rabelo LM, Souza Jr CV. Understanding Hospitalization in Patients with Heart Failure. Int J Cardiovasc Sci[Internet]. 2017 [cited 2018 Aug 05];30(1):81-90. Available from: http://dx.doi.org/10.5935/2359-4802.20160060 
4. Rogers C, Bush N. Heart Failure: Pathophysiology, Diagnosis, Medical Treatment Guidelines, and Nursing Management. Nurs Clin North Am [Internet]. 2015 [cited 2018 Jul 01];50(4):787-99. Available from: https://www.ncbi.nlm.nih.gov/pubmed/26596665

5. Albuquerque DC, Souza Neto JD, Bacal F, Rohde LEP, Pereira SB, Berwanger O, et al. I Brazilian Registry of Heart Failure - Clinical Aspects, Care Quality and Hospitalization Outcomes. Arq Bras Cardiol [Internet]. 2015 [cited 2018 Jun 13];104(6):433-42. Available from: https://www. scielo.br/pdf/abc/v104n6/0066-782X-abc-20150031.pdf

6. Rabelo-Silva ER, Saffi MAL, Aliti GB, Feijó MK, Linch GFC, Sauer JM, et al. Precipitating factors of decompensation of heart failure related to treatment adherence: multicenter study-EMBRACE. Rev Gaúcha Enferm [Internet] 2018 [cited 2018 Sep 13];39:e2017-0292. Available from: https://doi.org/10.1590/1983-1447.2018.2017-0292

7. Philipson H, Ekman I, Forslund HB, Swedberg K, Schaufelberger M. Salt and fluid restriction is effective in patients with chronic heart failure. Eur J Heart Fail [Internet]. 2013 [cited 2018 Jun 11];15(11):1304-10. Available from: https://doi.org/10.1093/eurjhf/hft097

8. Gupta D, Georgiopoulou VV, Kalogeropoulos AP, Dunbar SB, Reilly CM, Sands JM. Dietary sodium intake in heart failure. Circulation [Internet]. 2012 [cited 2018 Jun 11];126(4):479-85. Available from: https://www.ncbi.nlm.nih.gov/pubmed/22825409

9. Arcand J, Ivanov J, Sasson A, Floras V, Al-Hesayen A, Azevedo ER et al. A high-sodium diet is associated with acute decompensated heart failure in ambulatory heart failure patients: a prospective follow-up study. Am J Clin Nutr [Internet]. 2011 [cited 2018 Jun 11];93(2):332-7. Available from: https://www.ncbi.nlm.nih.gov/pubmed/21084647

10. Lennie TA, Chung ML, Moser DK. What should we tell patients with heart failure about sodium restriction and how should we counsel them? Curr Heart Fail Rep [Internet]. 2013 [cited 2018 Jun 17];10(3):219-26. Available from: https://www.ncbi.nlm.nih.gov/pmc/articles/PMC3774591

11. Rong X, Peng Y, Yu HP, Li D. Cultural factors influencing dietary and fluid restriction behavior: perceptions of older Chinese patients with heart failure. J Clin Nurs [Internet]. 2017 [cited 2018 Jun 17];26(5-6):717-26. Available from: https://www.ncbi.nlm.nih.gov/ pubmed/27532343

12. Mendes KDS, Silveira RCCP, Galvão CM. Integrative literature review: a research method to incorporate evidence in health care and nursing. Texto Contexto Enferm [Internet]. 2008 [cited 2018 Jun 19];17(4):758-64. Available from: http://dx.doi.org/10.1590/ S0104-07072008000400018

13. Santos CMC, Pimenta CAM, Nobre MRC. The PICO strategy for the research question construction and evidence search. Rev Latino-Am Enfermagem [Internet]. 2007 [cited 2018 Jun 19];15(3):508-11. Available from: http://dx.doi.org/10.1590/S0104-11692007000300023

14. Melnyk BM, Fineout-Overholt E. Making the case for evidence-based practice. In: Melnyk BM, Fineout-Overholt E. Evidence-based practice in nursing \& healthcare. A guide to best practice. Philadelphia: Lippincot Williams \& Wilkins; 2005. p.3-24.

15. Galvão TF, Pansani TSA, Harrad D. Principais itens para relatar revisões sistemáticas e meta-análises: A recomendação PRISMA. Epidemiol Serv Saúde [Internet]. 2015 [cited 2018 Jun 12];24(2):335-42. Available from: http://dx.doi.org/10.5123/S1679-49742015000200017

16. Colin-Ramirez E, McAlister FA, Zheng Y, Sharma S, Armstrong PW, Ezekowitz JA. The long-term effects of dietary sodium restriction on clinical outcomes in patients with heart failure. The SODIUM-HF (Study of Dietary Intervention Under $100 \mathrm{mmol}$ in Heart Failure): a pilot study. Am Heart J [Internet]. 2015 [cited 2018 Jun 19];169(2):274-81. Available from: https://www.ncbi.nlm.nih.gov/pubmed/25641537

17. Paterna S, Gaspare P, Fasullo S, Sarullo FM, Di Pasquale P. Normal-sodium diet compared with low-sodium diet in compensated congestive heart failure: is sodium an old enemy or a new friend? Clin Sci (Lond) [Internet]. 2008 [cited 2018 Jul 18];114(3):221-30. Available from: https://www.ncbi.nlm.nih.gov/pubmed/17688420

18. Son YJ, Lee Y, Song EK. Adherence to a sodium-restricted diet is associated with lower symptom burden and longer cardiac event-free survival in patients with heart failure. J Clin Nurs [Internet]. 2011 [cited 2018 Jul 20];20(21-22):3029-38. Available from: https://www.ncbi. nlm.nih.gov/pubmed/21707808

19. Basuray A, Dolansky M, Josephson R, Sattar A, Grady EM, Vehovec A, et al. Dietary sodium adherence is poor in chronic heart failure patients. J Card Fail [Internet]. 2015 [cited 2018 Jul 20];21(4):323-9. Available from: https://www.ncbi.nlm.nih.gov/pubmed/25576680

20. Welsh D, Lennie TA, Marcinek R, Biddle MJ, Abshire D, Bentley B et al. Low-sodium diet self-management intervention in heart failure: pilot study results. Eur J Cardiovasc Nurs [Internet]. 2013 [cited 2018 Jul 20];12(1):87-95. Available from: https://www.ncbi.nlm.nih.gov/ pubmed/22492785

21. Colin-Ramirez E, McAlister FA, Woo E, Wong N, Ezekowitz JA. Association between self-reported adherence to a low-sodium diet and dietary habits related to sodium intake in heart failure patients. J Cardiovasc Nurs [Internet]. 2015 [cited 2018 Jul 22];30(1):58-65. Available from: https://www.ncbi.nlm.nih.gov/pubmed/24598553

22. Doukky R, Avery E, Mangla A, Collado FM, Ibrahim Z, Poulin MF et al. Impact of Dietary Sodium Restriction on Heart Failure Outcomes. JACC Heart Fail [Internet]. 2016 [cited 2018 Jul 22];4(1):24-35. Available from: https://www.ncbi.nlm.nih.gov/pubmed/26738949

23. Heo S, Lennie TA, Moser DK, Okoli C. Heart failure patients' perceptions on nutrition and dietary adherence. Eur J Cardiovasc Nurs [Internet]. 2009 [cited 2018 Jul 23];8(5):323-8. Available from: https://www.ncbi.nlm.nih.gov/pubmed/19589729

24. Wu JR, Lennie TA, Dunbar SB, Pressler SJ, Moser DK. Does the Theory of Planned Behavior predict dietary sodium intake in patients with heart failure? West J Nurs Res [Internet]. 2016 [cited 2018 Jul 23];18. Available from: https://www.ncbi.nlm.nih.gov/pubmed/27756851

25. Chung ML, Park L, Frazier SK, Lennie TA. Long-term adherence to low-sodium diet in patients with heart failure. West J Nurs Res [Internet]. 2016 [cited 2018 Jul 25];30. Available from: https://www.ncbi.nlm.nih.gov/pubmed/27903829

26. Lennie TA, Worrall-Carter L, Hammash M, Odom-Forren J, Roser LP, Smith CS. Relationship of heart failure patients' knowledge, perceived 
barriers, and attitudes regarding low-sodium diet recommendations to adherence. Prog Cardiovasc Nurs [Internet]. 2008 [cited 2018 Jul 25];23(1):6-11. Available from: https://www.ncbi.nlm.nih.gov/pubmed/18326994

27. Song EK, Moser DK, Kang SM, Lennie TA. Self-reported adherence to a low-sodium diet and health outcomes in patients with heart failure. J Cardiovasc Nurs [Internet]. 2016 [cited 2018 Jul 25];31(6):529-34. Available from: https://www.ncbi.nlm.nih.gov/pubmed/26296246

28. Lennie TA, Song EK, Wu JR, Chung ML, Dunbar SB, Pressler SJ, et al. Three gram sodium intake is associated with longer event-free survival only in patients with advanced heart failure. J Card Fail [Internet]. 2011 [cited 2018 Jul 28];17(4):325-30. Available from: https://www.ncbi. nlm.nih.gov/pubmed/21440871

29. Colin-Ramirez E, Arcand J, Ezekowitz JA. Dietary self-management in heart failure: high tech or high touch? Curr Treat Options CardiovasC Med [Internet]. 2017 [cited 2018 Jul 28];19(3):19. Available from: https://www.ncbi.nlm.nih.gov/pubmed/28299612

30. Mills KT, Chen J, Yang W, Appel LJ, Kusek JW, Alper A, Sodium excretion and the risk of cardiovascular disease in patients with chronic kidney disease. JAMA [Internet] 2016 [cited 2018 Jul 22];315(20):2200-210. Available from: https://www.ncbi.nlm.nih.gov/pmc/articles/ PMC5087595/

31. Perin MS, Cornélio ME, Rodrigues RCM, Gallani MCBJ. Characterization of salt consumption among hypertensives according to sociodemographic and clinical factors. Rev Latino-Am Enfermagem [Internet]. 2013 [cited 2018 Jul 22];21(5):1013-21. Available from: http://www. scielo.br/pdf/rlae/v21n5/0104-1169-rlae-21-05-1013.pdf

32. Bentley B, Lennie TA, Biddle M, Chung ML, Moser DK. Demonstration of psychometric soundness of the Dietary Sodium Restriction Questionnaire in patients with heart failure. Heart Lung [Internet]. 2009 [cited 2018 Jul 27];38(2):121-8. Available from: https://www.ncbi. nlm.nih.gov/pubmed/19254630

33. Ajzen I. The theory of planned behavior. Organ Behav Hum Decis Process [Internet]. 1991[cited 2018 Jul 27];50:179-211. Available from: https://doi.org/10.1016/0749-5978(91)90020-T

34. Chung ML, Lennie TA, Mudd-Martin G, Moser DK. Adherence to the low sodium diet in patients with heart failure is best when family members also follow the diet: a multicenter observational study. J Cardiovasc Nurs [Internet]. 2015 [cited 2018 Jul 29];30(1):44-50. Available from: https://www.ncbi.nlm.nih.gov/pubmed/24165698

35. Almeida KSM, Souza GC, Rabelo ER. Cross-cultural Adaptation into Brazilian Portuguese of the Dietary Sodium Restriction Questionnaire (DSRQ). Arq Bras Cardiol [Internet]. 2012 [cited 2018 Jul 29];98(1):70-75. Available from: http://dx.doi.org/10.1590/ S0066-782X2011005000122 